\title{
Thinking in the sustainability of Nothofagus antarctica silvopastoral systems, how differ the responses of seedlings from different provenances to water shortage?
}

\author{
Héctor A. Bahamonde 1 - D. Sánchez-Gómez $\cdot$ J. Gyenge • \\ P. L. Peri · J. M. Cellini · I. Aranda
}

Received: 30 March 2017 / Accepted: 28 November 2017/Published online: 1 December 2017

(C) Springer Science+Business Media B.V., part of Springer Nature 2017

\begin{abstract}
Nothofagus antarctica, is the most important species of the silvopastoral systems of southern Patagonia. However, there is limited information on the ecophysiological response mechanisms of seedlings for survival under different resource availability regimes, and whether such processes may differ between provenances. In this study, we evaluated the functional response to water shortage of seedlings of four $N$. antarctica provenances grown under controlled conditions. After an initial full irrigation period, seedlings were subjected to a water shortage
\end{abstract}

H. A. Bahamonde $(\bowtie) \cdot$ P. L. Peri

Instituto Nacional de Tecnología Agropecuaria (INTA), cc 332, CP 9400 Río Gallegos, Santa Cruz, Argentina e-mail: bahamonde.hector@inta.gob.ar

H. A. Bahamonde · P. L. Peri

Universidad Nacional de la Patagonia Austral (UNPA), Lisandro de la Torre 1070, CP 9400 Río Gallegos,

Argentina

D. Sánchez-Gómez · I. Aranda

Intituto Nacional de Investigaciones y Tecnologías Agrarias y Alimentarias, Centro de Investigación Forestal (INIA-CIFOR), Carretera de La Coruña km 7.5, Madrid, Spain

D. Sánchez-Gómez

Instituto Regional de Investigación, Desarrollo Agroalimentario y Forestal de Castilla-La Mancha (IRIAF), Centro de Investigación Agroforestal de Albadalejito (CIAF), Ctra. Toledo-Cuenca km 174, 16194 Cuenca, Spain cycle. Measurements of the diameter at the base of the stem, net photosynthesis $\left(\mathrm{A}_{\mathrm{n}}\right)$, stomatal conductance to water vapour $\left(\mathrm{g}_{\mathrm{s}}\right)$, predawn water potential ( $\Psi_{\text {pd }}$ ), osmotic potential at maximum and zero turgor $\left(\Pi_{100} ; \Pi_{0}\right)$, relative water content at zero turgor $\left(\mathrm{RWC}_{0}\right)$ and maximum modulus of elasticity $\left(\mathrm{E}_{\max }\right)$ were carried out during the experimental period. Differences between provenances concerning An and $\mathrm{g}_{\mathrm{s}}$ rates were recorded under full irrigation conditions, but were not detected in association with drought stress. All provenances had similar osmotic

\footnotetext{
J. Gyenge · P. L. Peri

Consejo Nacional de Investigaciones Científicas y

Técnicas (CONICET), Buenos Aires, Argentina

J. Gyenge

AER Tandil, EEA Balcarce INTA, Gral. Rodríguez 370,

Tandil, Argentina

J. M. Cellini

Laboratorio de Investigación de Sistemas Ecológicos y Ambientales (LISEA), Universidad Nacional de La Plata, Diagonal 13 No 469, La Plata, Argentina
} 
potential values $\left(\Pi_{100}\right.$ and $\left.\Pi_{0}\right)$ at full irrigation, but water shortage led to significant osmotic potential differences between provenances. During the whole experimental period, no significant differences on $\mathrm{RWC}_{0}$ and $\mathrm{E}_{\max }$ values were recorded among provenances. Under full irrigation conditions, all $N$. antarctica provenances had a similar physiological performance which suggests that environmental conditions may be the main driver for phenotypic differences in this species. From the osmotic adjustment results gathered, it is derived that a major osmoregulation capacity in response to water shortage is a common feature of all the $N$. antarctica provenances evaluated.

Keywords Native forest $\cdot$ Nire .

Water stress - Photosynthesis - Osmotic adjustment

\section{Introduction}

The Nothofagus (Fagaceae) genus is one of the most representative tree genera of the southern hemisphere, being mainly distributed in temperate forests of Australia, New Zealand, and southern Chile and Argentina (Tanai 1986). In the last two countries, the deciduous Nothofagus antarctica (G. Forster) Oerst. (commonly known as "ñire" or "ñirre) is the species with the broadest ecological amplitude, thriving in a latitudinal range from $36^{\circ} 30^{\prime}$ to $56^{\circ} 00^{\prime} \mathrm{S}$ and an altitudinal gradient from 0 to $2000 \mathrm{~m}$ above sea level (Veblen et al. 1996). With an extension of 431,000 ha, the distribution of ñire forests in Argentinean southern Patagonia occupies the ecotone zone between the more productive $N$. pumilio forests, and the steppe where water availability conditions severely limit growth of forest trees (Collado 2001; Peri and Ormaechea 2013). This area includes contrasting environmental conditions such as poorly drained sites with high precipitations, or drier sites exposed to strong winds in the limit with the Patagonian steppe (Veblen et al. 1996). Furthermore, several studies in $N$. antarctica forests showed that stands located at different environmental conditions and under distinct use (e.g., unmanaged forests vs. thinned stands for silvopastoral use) have variable responses in terms of ecological and productive parameters (Peri et al. 2010; Ladd et al. 2014; Bahamonde et al. 2015; 2016a, b; Gargaglione et al.
2013). Approximately $70 \%$ of ñire native forests in Patagonia have been used as silvopastoral systems, also involving the removal of trees to increase forage and consequently meat production (Peri et al. 2016). However, according to the new Argentinean National Law of Minimum Environmental Standards for Native Forests (Law No 26331), silvopastoral systems, must ensure the continuity of the tree stratum. Related to this affair, studies carried out in $N$. antarctica forests in continental Patagonia showed that higher seedling installation occurred in forests with silvopastoral use compared to primary unmanaged forests (Bahamonde et al. 2016a). Nevertheless, the authors reported that at the end of the growing season the survival rate was often quite low in the first year and close to zero at the second year after seed germination. In contrast, in Tierra del Fuego (a large island of Southern Patagonia) seedling installation was reported to occur both in primary unmanaged and silvopastoral-used forests, creating a well-established seedling bank, where after 4 years, the amount of seedlings in silvopastoral use almost doubled that of primary forests (Peri et al. 2016). In this context, management of regeneration has been suggested as a strategy to promote the continuity of the arboreal stratum (Bahamonde et al. 2016a). However, there is limited knowledge on the ecophysiological mechanisms of seedling survival under different resource availability situations, also concerning the performance of different provenances. On the other hand, in the next decades an increase in temperatures and a decrease in precipitations are expected in Patagonia (3rd report of the Ministry of Environment and Sustainable Development of Argentina, MESP 2015), being the response of forest species to such future scenario totally uncertain. In general, seedlings of $N$. antarctica require high levels of light and soil moisture to survive with a more secondary role of site quality (Bahamonde et al. 2013; Soler et al. 2013). Previous reports indicate that seedlings may develop different strategies depending on the origin of the populations. This species has been observed to be sensitive to water and light constraints (Peri et al. 2009). Decreased photosynthetic net assimilation $\left(\mathrm{A}_{\mathrm{n}}\right)$ rates have been recorded when growing $N$. antarctica seedlings from northern Patagonia at low levels of light and soil moisture (Peri et al. 2009). Such study was however focused on analyzing the phenotypic response of seedlings 
Table 1 Main characteristics of Nothofagus antarctica forests from four provenances in southern Patagonia

\begin{tabular}{lllllll}
\hline Provenance & Geographical coordinates & Altitude (m a.s.l.) & MAP $\left(\mathrm{mm}\right.$ year $\left.{ }^{-1}\right)$ & MAT $\left({ }^{\circ} \mathrm{C}\right)$ & DH $(\mathrm{m})$ & Evtp $\left(\mathrm{mm} \mathrm{year}^{-1}\right)$ \\
\hline $\mathrm{CC} 2$ & $51^{\circ} 13^{\prime} 21^{\prime \prime} \mathrm{S}-72^{\circ} 15^{\prime} 44^{\prime \prime} \mathrm{W}$ & 295 & 520 & 5.9 & 11.7 & 696 \\
$\mathrm{CC} 4$ & $51^{\circ} 17^{\prime} 11^{\prime \prime} \mathrm{S}-72^{\circ} 15^{\prime} 00^{\prime \prime} \mathrm{W}$ & 250 & 450 & 5.5 & 8 & 718 \\
$\mathrm{TM}$ & $51^{\circ} 19^{\prime} 05^{\prime \prime} \mathrm{S}-72^{\circ} 10^{\prime} 47^{\prime \prime} \mathrm{O}$ & 452 & 400 & 5.1 & 5 & 736 \\
$\mathrm{TDF}$ & $54^{\circ} 20^{\prime} 03^{\prime \prime} \mathrm{S}-67^{\circ} 52^{\prime} 04^{\prime \prime} \mathrm{W}$ & 90 & 640 & 5.1 & 13.6 & 571 \\
\hline
\end{tabular}

$M A P$ mean annual precipitation, MAT mean annual temperature, $D H$ dominant height of mature trees, Evtp potential annual evapotranspiration

from a single provenance. Nevertheless, information about intra-specific variability in $N$. antarctica is scarce. This intra-specific variability in response to water stress in gas exchange parameters has been assessed for other genus and species of Fagaceae, such as Quercus sp. (Arend et al. 2011), Fagus sp. (Sánchez-Gómez et al. 2013) or Nothofagus pumilio (Premoli and Brewer 2007).

Some investigations analyzed inter-specific differences in the Nothofagus genus focussed on traits related to leaf water relations. Varela (2010) evaluated the osmotic adjustment of $N$. nervosa and $N$. obliqua (closely related species to $N$. antarctica) through pressure-volume curves, but no significant differences were recorded between treatments (wellwatered vs. water stressed plants). Variations in hydraulic properties of leaves and shoots, and xylem anatomy of different Nothofagus species have been recently assessed (Bucci et al. 2013; Dettmann et al. 2013). However, few studies examined the functional response of $N$. antarctica to water shortage comparing plants from different provenances.

Considering that: (i) the use of Nothofagus antarctica forests under silvopastoral systems must ensure the continuity of arboreal stratum; (ii) management of regeneration is necessary to reach the previous goal; and (iii) increased temperatures and decreased precipitations are expected in Patagonia in the near future, it proves essential to assess the response of seedlings to environmental changes (Peri et al. 2016). Therefore, the aim of this investigation was to evaluate the functional responses of $N$. antarctica seedlings from different provenances of southern Patagonia to water shortage by analyzing gas exchange parameters and osmotic adjustment capacity. Our main hypothesis was that the population native to the area having the most severe environmental conditions (i.e., lower precipitation, higher evapotranspiration and lower temperature) would be able to display a better response to the water shortage.

\section{Materials and methods}

\section{Plant material}

Seeds of $N$. antarctica from four provenances (CC2, CC4, TM and TDF) of southern Patagonia were collected at different locations during March (2014). These provenances are a combination of contrasting geographical, climatic and local environmental conditions, which results in contrasting phenotypic trees in the field. The major contrasting conditions between provenances are mainly related to the TM and TDF sites, the first (TM) being located at a higher altitude, with a lower annual precipitation and higher potential evapotranspiration than the last (TDF) one (Table 1). Such different environmental conditions are consistent with the major differences observed in the height of mature dominant trees, having $5 \mathrm{~m}$ in the TM provenance, $13.6 \mathrm{~m}$ in the TDF provenance (Table 1).

\section{Experimental design}

Seeds from the four provenances were germinated as described by Bahamonde et al. (2011) and planted in $100 \mathrm{cc}$ trays. The number of seedlings obtained was 9, 10, 6 and 12 for $\mathrm{CC} 2, \mathrm{CC} 4, \mathrm{TM}$ and TDF provenances, respectively. In a first initial growth phase of two months, seedlings were well watered and kept in a greenhouse with $25 / 18{ }^{\circ} \mathrm{C}$ (day/night) temperature and a mean of $60 \%$ relative humidity. Thereafter, seedlings were carefully transplanted to 2 $\mathrm{L}$ pots and grown for 6 months in a climatic chamber under a photoperiod of 14/10 h of light/darkness, a 
temperature range of $25{ }^{\circ} \mathrm{C}$ day/20 ${ }^{\circ} \mathrm{C}$ night, $65 \%$ relative humidity and a PPFD (photosynthetic photon flux density) at the top of $800 \mu \mathrm{mol} \mathrm{m}{ }^{-2} \mathrm{~s}^{-1}$. After 5 months of maintaining plants well-watered, seedlings were submitted to a water stress cycle for one additional month by decreasing watering on a weekly basis. Thus, plants were kept from field capacity (FC) to $70 \% \mathrm{FC}, 50 \% \mathrm{FC}, 40 \% \mathrm{FC}$ and $33 \% \mathrm{FC}$, over the next 4 weeks, respectively. Plant water status was established by measuring both predawn water potential $\left(\Psi_{\mathrm{pd}}\right)$ with a Scholander pressure chamber (Soil Moisture Equipment Corp, Santa Barbara, CA, USA), and gas exchange rates $\left(\mathrm{T}_{0}\right.$ and $\mathrm{T}_{\mathrm{F}}$, see next section). The soil water content in the pots was recorded (SWC) at different times during the drought stress cycle by capacitance/frequency domain sensors (10HS Large Soil Moisture sensor, connected to ProCheck data logger, Decagon Devices).

Leaf functional and morphological parameters measurements

The diameter at the base of seedling stems was measured at the fourth month of growth at the climatic chamber (hereafter $\mathrm{T}_{0}$ ), after 30 days (i.e., at the end of full irrigation cycle, $\mathrm{T}_{0.5}$ ) and by the end of the experimental period (i.e., after 6 months, by the end of water stress cycle, hereafter referred to as $T_{F}$ ). The relative diameter growth at the base of stem seedling was subsequently calculated between $T_{0}$ and $T_{0.5}$ (well-watered period) and between $\mathrm{T}_{0.5}$ and $\mathrm{T}_{\mathrm{F}}$ (water stressed period). The gas exchange parameters measured with a Li-Cor 6400 portable photosynthesis system equipped with the chamber LFC-40 (LICOR Inc., Lincoln, NE, USA) were: net photosynthesis $\left(A_{n}\right)$, transpiration rate $(E)$, chlorophyll fluorescence and stomatal conductance to water vapour $\left(\mathrm{g}_{\mathrm{s}}\right)$ at $\mathrm{T}_{0}$ and $\mathrm{T}_{\mathrm{F}}$. Leaves were exposed to a fixed $\mathrm{CO}_{2}$ concentration of $400 \mathrm{ppm}$ using the built-in Li-Cor 6400-01 $\mathrm{CO}_{2}$ mixer (Li-Cor, Inc.), a PPFD of $1200 \mu \mathrm{mol} \mathrm{m}{ }^{2} \mathrm{~s}^{-1}$ (15\% blue light), using the Li-Cor 6400-40 fluorescence chamber (Li-Cor, Inc.), a temperature of $24^{\circ} \mathrm{C}$, a leaf-to-air vapor pressure deficit of $1.1 \mathrm{kPa}$ and a $\mathrm{RH}$ of $60-65 \%$. Measurements were carried out at $\mathrm{T}_{0}$ (well watered period) and $\mathrm{T}_{\mathrm{F}}$ (end of the water stress cycle). The intrinsic water use efficiency $\left(W U E_{i}\right)$ was calculated as $A_{n} / \mathrm{g}_{\mathrm{s}}$ in $\mu \mathrm{mol}$ fixed $\mathrm{CO}_{2}$ per mmol transpired $\mathrm{H}_{2} \mathrm{O}$. Once gas exchange measurements were completed, the projected leaf area was estimated by cutting the section of leaves that was enclosed into the chamber, scanning them, and analyzing the images using the ImageJ software (Rasband 1997-2004). This procedure was employed because the leaves were too small to occupy the entire area of the measuring chamber. The calculated measuring leaf area was used to recalculate the gas exchange results with the standard algorithms provided by the Li-Cor 6400 simulator. At each date of measurement, fresh leaves from all the treatments without the petiole were scanned and leaf areas were estimated by image analyses as indicated above. Leaves were subsequently dried at $65{ }^{\circ} \mathrm{C}$ for three days and weighted for estimating the specific leaf area (SLA). In addition, one leaf per plant was sampled, and the following water relation parameters were inferred by building $\mathrm{P}-$ $\mathrm{V}$ curves (Corcuera et al. 2002): osmotic potential at maximum and zero turgor $\left(\Pi_{100} ; \Pi_{0}\right)$, relative water content at zero turgor $\left(\mathrm{RWC}_{0}\right)$, relative water content of the apoplast $\left(\mathrm{RWC}_{\mathrm{a}}\right)$, maximum modulus of elasticity $\left(\mathrm{E}_{\max }\right)$, and dry/full-hydrated weight ratio (DW/TW). Plant water status and soil water availability were recorded from measuring predawn water potential ( $\left.\Psi_{\mathrm{pd}}\right)$ at the beginning (well watered period) and the end of the experiment (water stress).

To evaluate the phenotypic response of seedlings to water stress, the phenotypic plasticity index (PPI, Valladares et al. 2006) was calculated as follows:

PPI $=($ Maximum mean $X-$ Minimum mean $X) /$ Maximum mean $X$, where $X$ represents the parameter to be evaluated.

\section{Data analysis}

Exploratory testings were carried out to verify the compliance with the assumptions of normality, homoscedasticity and independence of data for each evaluated situation. While the Shapiro-Wilk test was performed to verify the normality of the data, the Levene test was used to verify homoscedasticity. The independence was verified by analysing residuals from graphs. Leaf functional and morphological parameters of seedlings were analysed with ANOVA for repeated measures with provenances as betweensubject factor and each measuring date as withinsubject factor. This analysis was performed because the values are not independent of time. Tukey tests were carried out to test differences between factors when F-values were significant $(P<0.05)$. The 

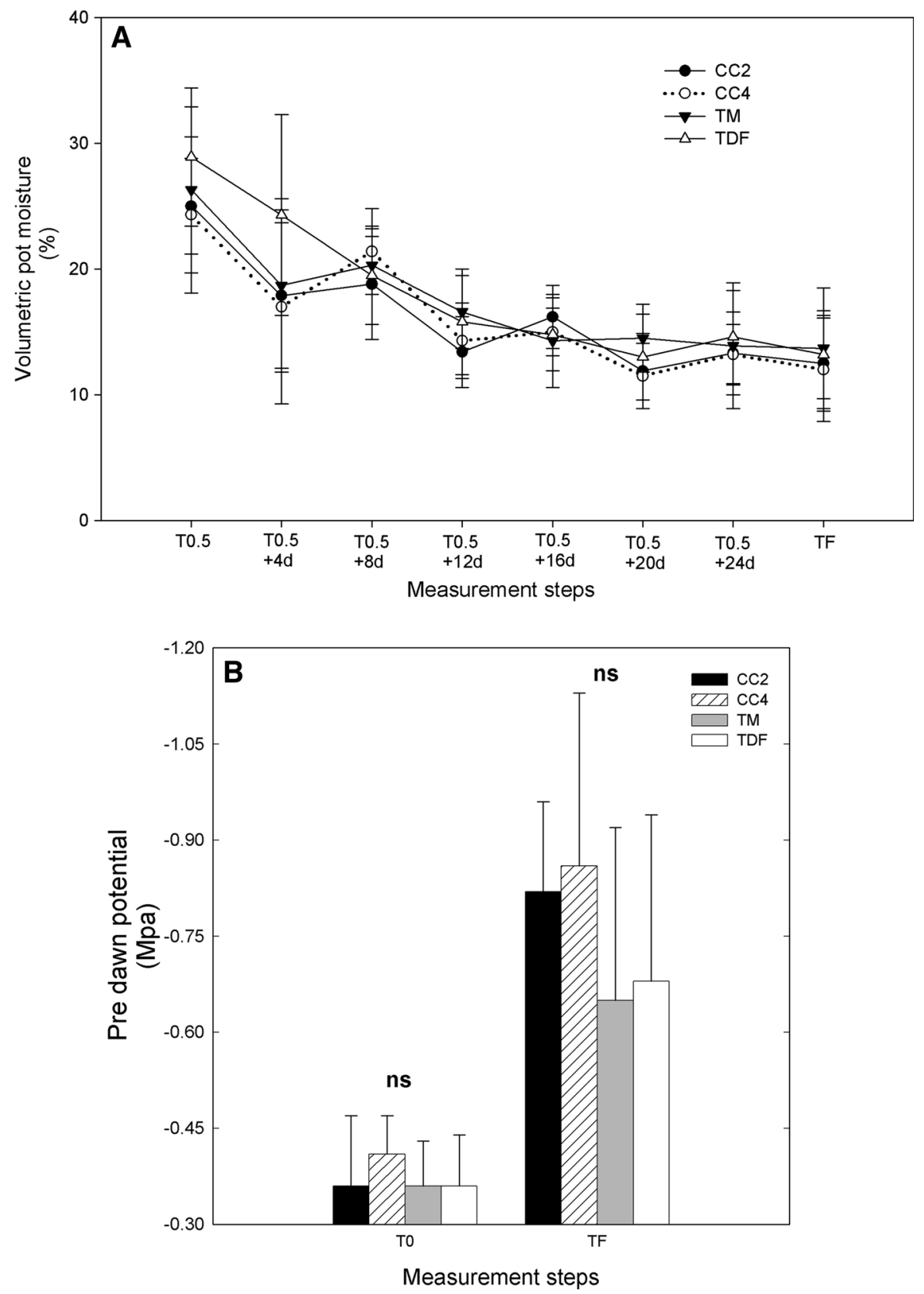

Fig. 1 Volumetric pot moisture (a) and pre-dawn potential (b) in Nothofagus antarctica seedlings from four provenances at different dates. The bars are the standard deviation of the mean. $T_{0}$ well-watered plants, $T_{0.5}$ end of well-watered period,

mean values of phenotypic plasticity index, considering all parameters, between provenances were compared with ANOVA.
$T_{F}$ water shortage, $d$ days. Different letters in a same date indicate significant differences $(\mathrm{P}<0.05)$ between provenances; $n s$ not significant

\section{Results}

The volumetric soil water content at the end of the regular watering period $\left(\mathrm{T}_{0.5}\right)$ averaged $28 \%$ and 

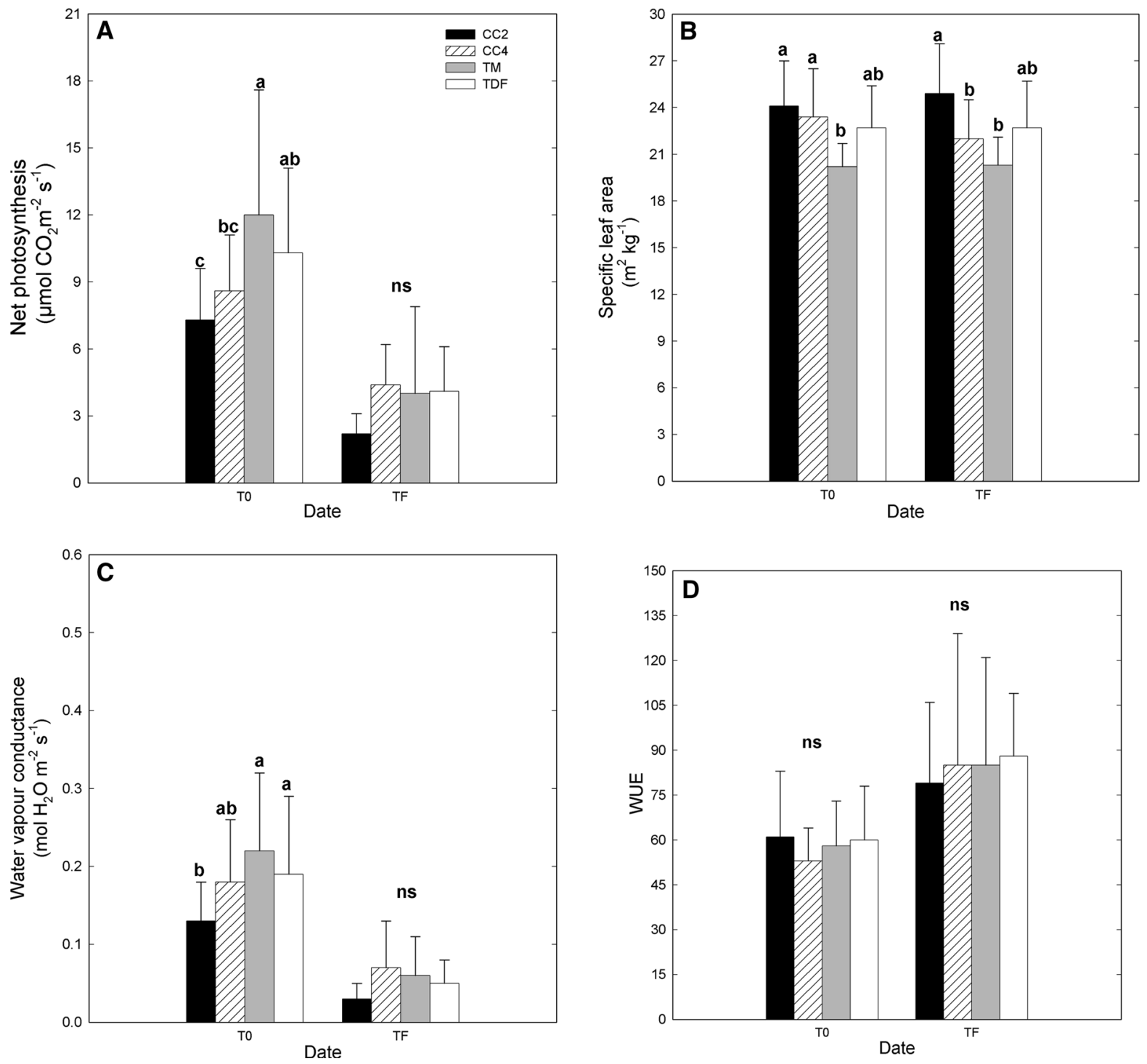

Fig. 2 Net photosynthesis (a), specific leaf area (b), stomatal water vapour conductance (c) and intrinsic water use efficiency (d) in Nothofagus antarctica seedlings from four provenances at different dates. The bars are the standard deviation of the

decreased to $14 \%$ at the end of water shortage period (Fig. 1a), with no differences being recorded between provenances $(\mathrm{P}>0.05)$. Similarly, the pre-dawn potential of plants varied from -0.38 to $-0.76 \mathrm{MPa}$, for well-watered and water-stressed plants, respectively (Fig. 1b). Non-significant differences were observed between provenances within each treatment. The net photosynthetic rate (An) was different between provenances when well-watered plants were compared $\left(\mathrm{T}_{0}\right)$, but these differences vanished at the

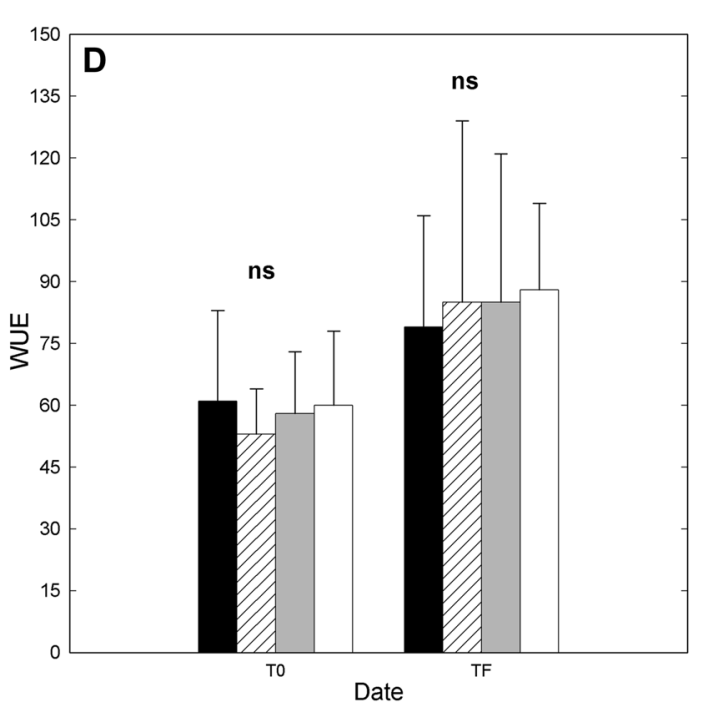

mean. $T_{0}$ well watered plants, $T_{F}$ water shortage. Different letters in a same date indicate significant differences $(\mathrm{P}<0.05)$ between provenances; $n s$ not significant

peak of the water shortage period $\left(\mathrm{T}_{\mathrm{F}}\right.$, Fig. 2a). When we compared the percentage of An reduction with water shortage according to provenances, the higher decrease was measured in $\mathrm{CC} 2$ and $\mathrm{TM}$ with an average of $66 \%$, and significantly higher $(\mathrm{P}<0.05)$ than to CC4 $(46 \%)$ and the TDF provenance $(55 \%)$. Specific leaf area (SLA) values were lower for the TM provenance regardless of the irrigation regime, with no differences being observed among sampling dates $(\mathrm{P}>0.05)$ at all (Fig. 2b). Significant stomatal 

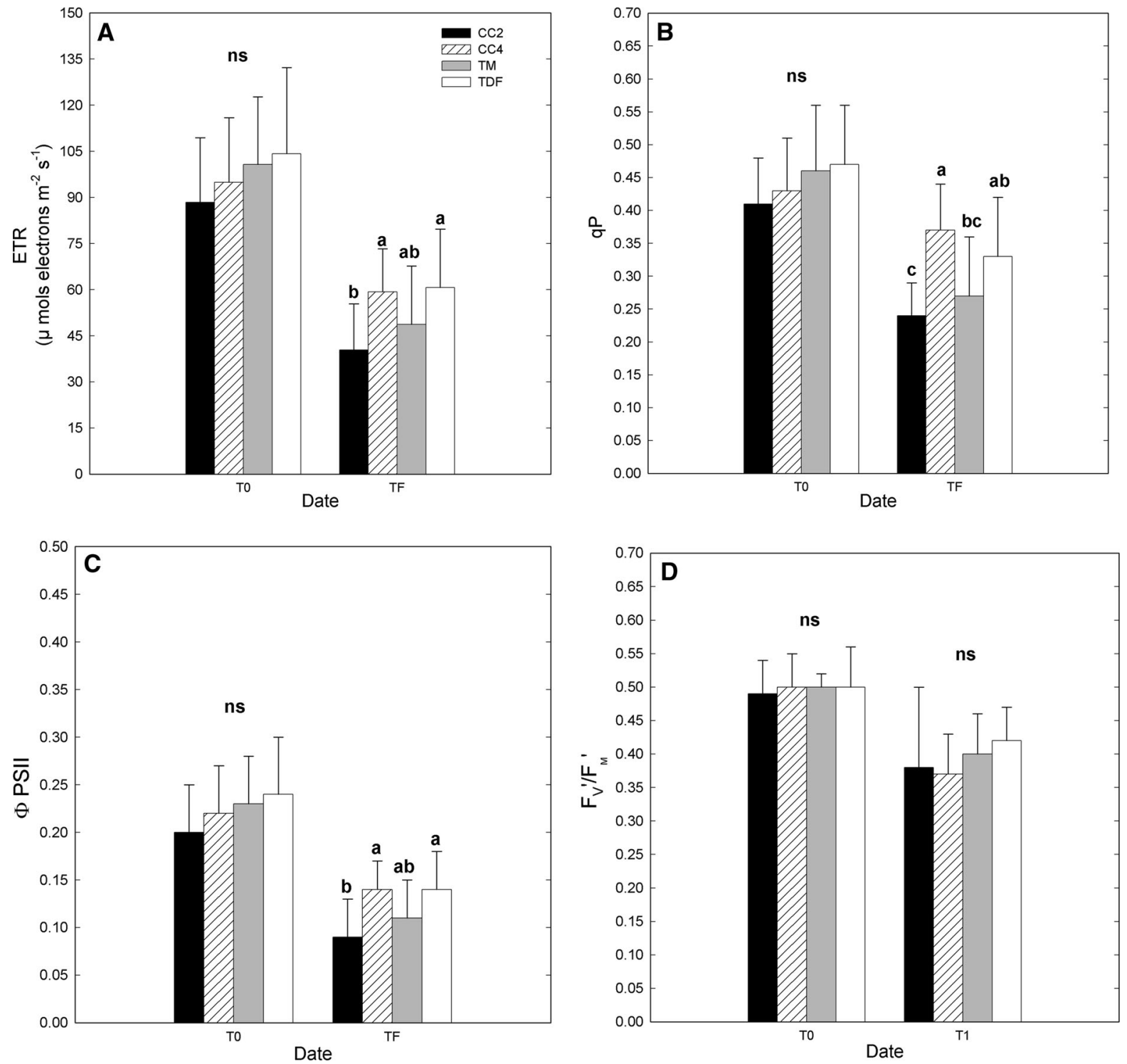

Fig. 3 Electrons transport rate (a), photochemical quenching (b), quantum yield of photosystem II (c) and intrinsic quantum yield of photosystem II (d) in Nothofagus antarctica seedlings from four provenances at different dates. The bars are the

conductance $\left(\mathrm{g}_{\mathrm{s}}\right)$ and An differences were observed between provenances when the plants were well watered, being the $\mathrm{CC} 2$ values the lowest recorded (Fig. 2c). The reduction of leaf stomatal conductance after water shortage $(\mathrm{TF})$ was significant $(\mathrm{P}<0.001)$ for all provenances, but there were no differences between them. The intrinsic water use efficiency was similar between provenances under the two irrigation regimes (i.e., well-watered and water shortage) (Fig. 2d). Comparing between dates and for all

standard deviation of the mean. $T_{0}$ well-watered plants, $T_{F}$ water shortage. Different letters in a same date indicate significant differences $(\mathrm{P}<0.05)$ between provenances; $n s$ not significant

provenances, the WUE was higher at $T_{F}$ (peak of water shortage), but the increase was only significant $(\mathrm{P}<0.05)$ in $\mathrm{CC} 4$.

The electron transport rate (ETR), photochemical quenching (qP) and the quantum yield of photosystem II ( $\Phi$ PSII) did not vary between provenances at the beginning of the trial $\left(\mathrm{T}_{0}\right)$, but decreased significantly $(\mathrm{P}<0.05)$ with water shortage depending on the provenance, being $\mathrm{CC} 2$ the lowest value recorded under water stress conditions (Fig. 3a-c). On the 


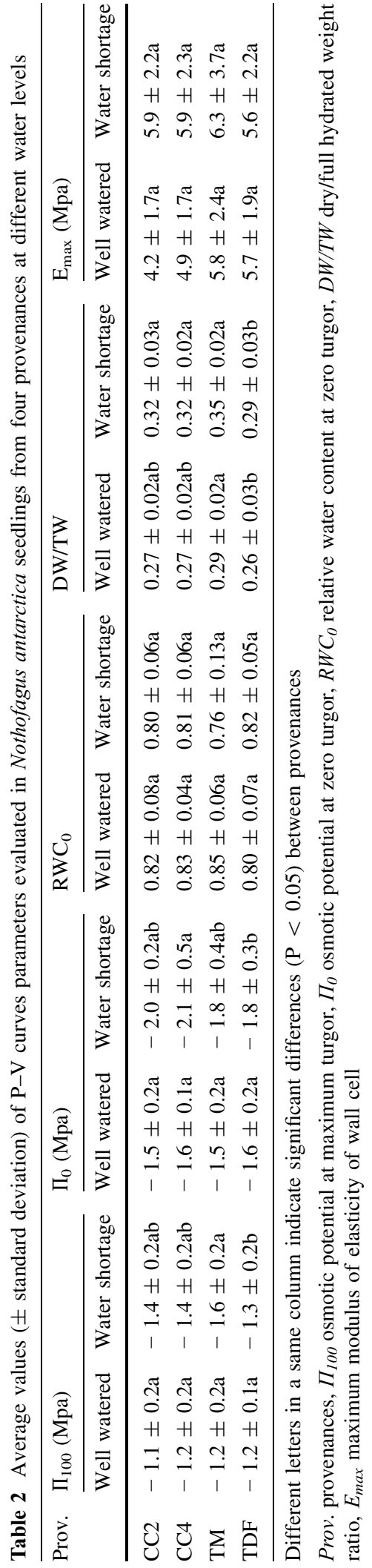

other hand, the intrinsic quantum yield of photosystem II $\left(\mathrm{F}_{\mathrm{V}}{ }^{6} / \mathrm{F}_{\mathrm{M}}{ }^{\mathrm{c}}\right)$ was not different between provenances (neither at the beginning nor the end of the experiment, Fig. 3d), but decreased significantly $(\mathrm{P}<0.05)$ between dates in all cases excepting TM.

Osmotic potentials at maximum $\left(\Pi_{100}\right)$ and zero turgor $\left(\Pi_{0}\right)$ were not different between provenances when plants were well watered, but after water shortage there was a general decrease and differences between provenances were significant (Table 2). When comparing $\Pi_{100}$ in seedlings of each provenance among dates, only the plants from TM showed a significant decrease in response to water shortage $(\mathrm{P}<0.05)$. In the case of $\Pi_{0}$, there were significant differences among dates, and the lowest values were recorded after water shortage with no clear differences between populations (Table 2). Both the relative water content at zero turgor $\left(\mathrm{RWC}_{0}\right)$ and maximum modulus of elasticity $\left(\mathrm{E}_{\max }\right)$, did not vary between provenances and no differences were detected among dates. The Dry to full-hydrated weight ratio (DW/TW) was different between plants from TM and TDF, being the values lower in TDF before and after water shortage. Values were significant higher $(\mathrm{P}<0.05)$ after water shortage in all provenances.

Although differences in the diameter at the base stem were minimal between provenances at $T_{0}$, after one month $\left(\mathrm{T}_{0.5}\right)$ such differences were not detectable during the remaining experimental period $\left(\mathrm{T}_{\mathrm{F}}\right.$ ) (Fig. 4a). The relative growth rate did not vary between origins during the well-watered period $\left(\mathrm{T}_{0}-\right.$ $\mathrm{T}_{0.5}$ ) or during the water shortage period $\left(\mathrm{T}_{0.5}-\mathrm{T}_{\mathrm{F}}\right)$ (Fig. 4b). However, comparing among periods, the relative growth rate was significantly lower $(\mathrm{P}<0.05)$ during the water shortage period in all the provenances.

The calculated phenotypic plasticity indexes varied between provenances depending of each parameter, however average values of all parameters were not significantly different between provenances (Table 3).

\section{Discussion}

In this study, we recorded variable responses to soil water deficits by comparing four different $N$. 


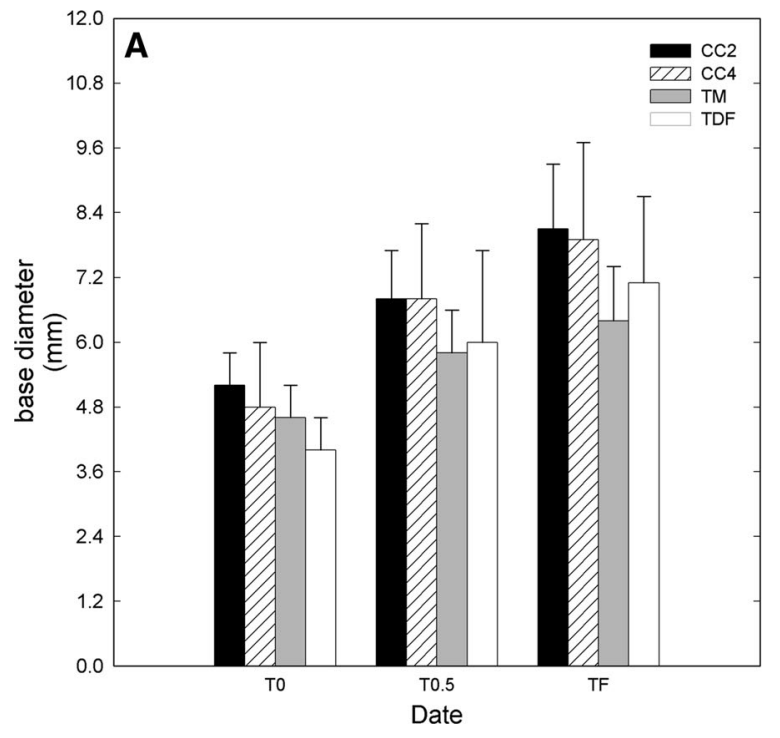

Fig. 4 Base diameter of the stem (a) and relative growth rate (b) in Nothofagus antarctica seedlings from four provenances at different dates. The bars are the standard deviation of the mean. $T_{0}$ well watered plants, $T_{0.5}$ end of well watered period,

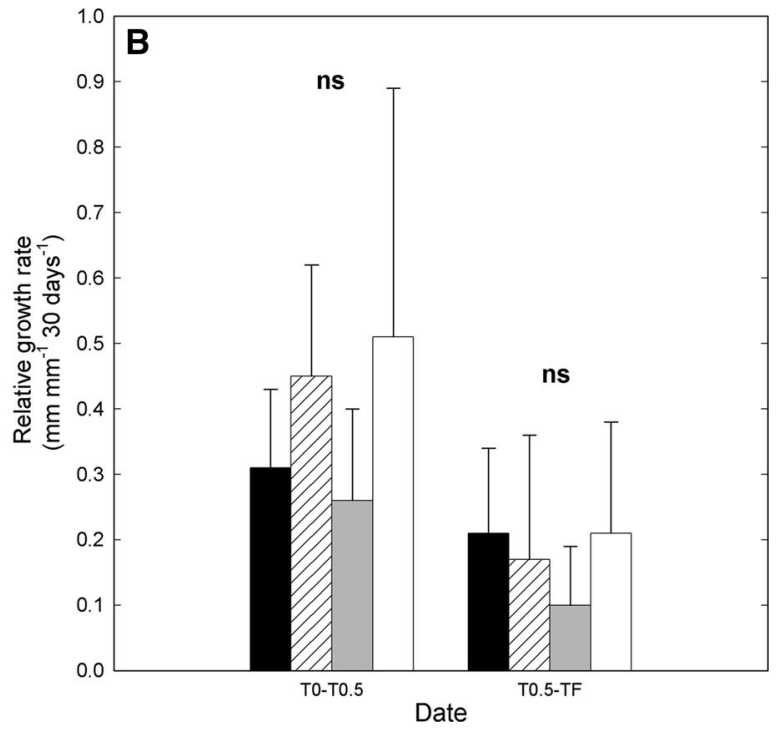

$T_{F}$ water sortage. Different letters in a same date indicate significant differences $(\mathrm{P}<0.05)$ between provenances; $n s$ not significant

Table 3 Phenotypic plasticity index of functional and physiological parameters evaluated in Nothofagus antarctica seedlings from four provenances

\begin{tabular}{llllllllllllllllll}
\hline Provenance & An & Swvc & WUEi & SLA & RGR & ETR & qP & FPSII & F'V/F'M $^{\prime}$ & OP_100 & OP_0 & RWC & DW/TW & E $_{\text {max }}$ & Average $^{a}$ \\
\hline CC2 & 0.70 & 0.77 & 0.29 & 0.03 & 0.63 & 0.54 & 0.41 & 0.55 & 0.22 & 0.27 & 0.33 & 0.02 & 0.19 & 0.40 & 0.38 \\
CC4 & 0.49 & 0.61 & 0.62 & 0.06 & 0.75 & 0.38 & 0.14 & 0.36 & 0.26 & 0.17 & 0.31 & 0.02 & 0.19 & 0.20 & 0.33 \\
TM & 0.67 & 0.73 & 0.46 & 0.01 & 0.74 & 0.52 & 0.41 & 0.52 & 0.20 & 0.33 & 0.20 & 0.11 & 0.21 & 0.09 & 0.37 \\
TDF & 0.60 & 0.74 & 0.47 & 0.01 & 0.74 & 0.42 & 0.30 & 0.42 & 0.16 & 0.08 & 0.13 & 0.02 & 0.12 & 0.02 & 0.30 \\
\hline
\end{tabular}

$A n$ net photosynthesis, $S w v c$ stomatal water vapour conductance, WUEi intrinsic water use efficiency, $S L A$ specific leaf area, $R G R$ relative growth rate of seedlings, ETR electrons transport rate, $q P$ photochemical quenching, FPSII quantum yield of photosystem II, $F^{\prime} V / F^{\prime} M$ intrinsic quantum yield of photosystem II, $O P \_100$ osmotic potential at maximum turgor, $O P \_0$ osmotic potential at zero turgor, $R W C_{0}$ relative water content at zero turgor, $D W / T W$ dry/full hydrated weight ratio, $E_{\text {max }}$ maximum modulus of elasticity of wall cell

a Not significant differences were found in the average between provenances

antarctica provenances. The leaf net photosynthesis rates (An) measured in the four $N$. antarctica populations are similar to those reported by Peri et al. (2009) for two-year-old seedlings of this species in northern Patagonia, which reached maximum values of $11.1 \mu \mathrm{mol} \mathrm{CO}_{2} \mathrm{~m}^{-2} \mathrm{~s}^{-1}$ and near to zero in well-watered and water-stressed plants, respectively. However, these values are lower than those recorded for other Nothofagus spp. of this region. Peri et al. (2009) reported values of $16.8 \mu \mathrm{mol} \mathrm{CO} \mathrm{CO}^{-2}$ $\mathrm{s}^{-1}$ and Varela (2010) measured $13.6 \mu \mathrm{mol} \mathrm{CO} \mathrm{Cm}^{-2}$ $\mathrm{s}^{-1}$ for well-watered $N$. nervosa and $N$. obliqua seedlings. In our study, the highest An rate recorded for the provenance native of the highest altitude (TM) was coincident with the results of Premoli and Brewer (2007), who also measured higher An values in plants of $N$. pumilio from higher altitudes in a common garden experiment. Nevertheless, this should be interpreted with caution because altitude is not the only environmental difference between the provenances analysed, and the number of populations was low to infer a relationship between maximum 
photosynthetic capacity and altitude, or growing season's length as observed in other studies (Lajtha and Getz 1993; Hovenden and Brodribb 2000).

The negative effect of drought stress on photosynthesis is well documented (Bréda et al. 2006). In our study, the origin of the seedlings affected their photosynthetic responses to water shortage according to the observed differences in the reduction of An when comparing well-watered and water-stressed plants. This implies that the differences between provenances when seedlings were well watered, were not maintained after water shortage, and may reflect a different performance in terms of the phenotypic plasticity of the studied provenances, as corroborated by the phenotypic plasticity index determined. There is no preliminary information on tree inter-provenance variability in response to water shortage of $N$. antarctica. However, several studies carried out with trees and other woody species reported inter-provenance variability in response to drought stress (e.g., García-Plazaola and Becerril 2000; Atzmon et al. 2004; Ramírez-Valiente et al. 2010; Sánchez-Gómez et al. 2013).

The SLA values recorded in this study are higher than those measured by Calabria and Puntieri (2008) for $N$. dombeyi growing in northern Patagonia at two different light levels, and are also above the values of $N$. cunninghamii measured at different altitudes and two light levels in Tasmania (Hovenden and Vander Schoor 2006). Although changes in this foliar trait have been often associated with different light levels, investigations carried out with other species recorded SLA changes in response to drought (e.g., Liu and Stützel 2004). However, in this work we did not observe an effect of water availability on SLA, which is coherent with the $N$. antarctica results gathered by Bahamonde et al. (2014), where SLA was sensitive to light, but not to water availability. The transpiration rate (E) followed a similar trend to photosynthesis, both between different provenances and measuring dates. The values of $\mathrm{E}$ determined in this study for well-watered and water-stressed seedlings were higher and similar, respectively to those reported by Piper et al. (2007) for $N$. nitida and $N$. dombeyi seedlings growing at water potentials higher (less negative) than - 1.5 Mpa. Concerning $\mathrm{WUE}_{\mathrm{i}}$, our values were higher than those reported by Piper et al. (2007) at water potentials $>-1.5 \mathrm{Mpa}$, and similar to those determined for seedlings subjected to severe drought stress (water potential $<-2.5 \mathrm{Mpa}$ ). Although it might be expected an increase of $\mathrm{WUE}_{\mathrm{i}}$ in response to drought (Ogaya and Peñuelas 2003; Yin et al. 2005), we observed that water shortage did not affect $\mathrm{WUE}_{\mathrm{i}}$, which was only significantly higher in the $\mathrm{CC} 4$ provenance, may be due to a genetic effect as suggested by Read and Farquhar (1991).

Reduction in ETR in response to drought has also been reported for several species, and has been suggested as a mechanism to protect leaf photochemistry from reactive oxygen species production (Flexas et al. 1999; Golding and Johnson 2003). Photochemical quenching $(\mathrm{qP})$ and $\Phi$ PSII followed a similar decreasing trend with water shortage, which agrees with the results obtained by Piper et al. (2007) with two different Nothofagus spp. and other species (Golding and Johnson 2003). Our results suggest that regardless of the provenance, water shortage affected (decreased) the quantum yield of PSII. This is interpreted as a consequence of a decrease in $\mathrm{qP}$ and the intrinsic quantum yield of PSII in most provenances, with the exception of TM, for which the reduction on $\Phi$ PSII was only due to decreased of qP.

The stomatal conductance $\left(g_{s}\right)$ values measured in this study were lower than those reported by Peri et al. (2009) for $N$. antarctica and $N$. pumilio seedlings at similar water potentials, but these measurements were performed in two-year-old seedlings. The decrease of gs recorded in our investigation was similar to the previously found in this (Peri et al. 2009) and other Nothofagus spp. (Piper et al. 2007).

Read et al. (2010) evaluated twenty-three Nothofagus spp. from tropical and temperate forests, including evergreen and deciduous species as $N$. antarctica. Most of the parameters derived from $\mathrm{P}-\mathrm{V}$ curves in our study were very close to those of Read et al. (2010) for deciduous Nothofagus spp, but the $\mathrm{E}_{\max }$ was lower in our study. Read et al. (2010) suggested that deciduous Nothofagus spp. appear to have lower physiological drought resistance in comparison to temperate and tropical evergreen species. According to these findings, $N$. antarctica seedlings from all the provenances evaluated, did not show osmotic adjustment in response to the water shortage. Only when all the provenances were considered together as a whole, it was observable an osmotic adjustment at the species level. Similarly, Varela (2010) did not find evidence for an osmotic 
adjustment when seedlings of $N$. obliqua and $N$. nervosa were subjected to water stress in Northern Patagonia. Variability in osmotic adjustment in response to drought has been found across species from different water regimes, and also between populations within a species with contrasting water availability. This mechanism of drought tolerance may not be well developed in the genera, as it has been frequently observed for other Fagaceaes such as Quercus spp. (Aranda et al. 2004). These authors found osmotic adjustment in Quercus pyrenaica and $Q$. petraea seedlings when exposed to three consecutive water stress cycles, being the osmoregulatory capacity higher in $Q$. pyrenaica. This finding is interpreted by the authors in terms of higher adaptative capacity to drought of $Q$. pyrenaica than $Q$. petraea. Similarly, Nguyen-Queyrens and BouchetLannat (2003) evaluated the osmotic adjustment in response to water stress in Pinus pinaster seedlings from five provenances with contrasting soil water availability. These authors reported significant differences in osmotic adjustment among provenances and a significant negative relationship between the level of osmotic adjustment and the precipitation of the origin of the provenances.

High correlations between stem base diameter and aerial or total biomass have been found in seedlings of different species (Curt et al. 2005; Achten et al. 2010). In this study, water shortage had a similar effect on all provenances, decreasing the relative growth rate of the stem diameter. Similarly, Varela (2010) reported a reduction in leaf and shoot biomass, and height relative growth in water-stressed seedlings of $N$. nervosa and $N$. obliqua that are close related species to $N$. antarctica.

\section{Final considerations}

As a general trend, the four provenances of $N$. antarctica evaluated had a similar performance during the well-watered period, which suggests that environmental conditions may be the main driver for phenotypic differences of this species (e.g., dominant height of mature trees). Similarly, Premoli and Brewer (2007) reported that differences in ecophysiological traits of $N$. pumilio found under field conditions were not observed in a common garden experiment, suggesting a major effect of the environment. Furthermore and contrary to our preliminary hypothesis, the water shortage did not trigger different apparent physiological responses between provenances. It is concluded that further field and common garden studies are necessary to improve our understanding of the eco-physiological response of these species to different stress factors. Regarding osmotic adjustment and in agreement with previous reports, it is concluded that either higher water deficits may be necessary to generate a response, or that a true capacity of osmoregulation in response to drought is a common feature of all the provenances evaluated. The results obtained provide information on response of Nothofagus antarctica seedlings to drought but future studies should be carried out for understanding of $N$. antarctica water economy in a context of climate change and as tool for improving forest silvopastoral use in southern Patagonia.

Acknowledgements We are very grateful to Rosina Soler for helping with the collection of seeds and Victoria Fernández for helping with language revision.

\section{References}

Achten WMJ, Maes WH, Reubens B, Mathijs E, Singh VP, Verchot L, Muys B (2010) Biomass production and allocation in Jatro phacurcas L. Seedlings under different levels of drought stress. Biomass Bioener 34:667-676

Aranda I, Gil L, Pardos JA (2004) Osmotic adjustment in two temperate oak species [Quercus pyrenaica Willd and Quercus petraea (Matt.) Liebl] of the Iberian Peninsula in response to drought. Invest Agrar 13:339-345

Arend M, Kuster T, Gúnthardt-Goerg MS, Dobbertin M (2011) Provenance-specific growth responses to drought and air warming in three Eurpean oak species (Quercusrobur, $Q$. petraea and $Q$. pubescens). Tree Physiol 31:287-297

Atzmon N, Moshe Y, Schiller G (2004) Ecophysiological response to severe drought in Pinus halepensis Mill. Trees of two provenances. Plant Ecol 171:15-22

Bahamonde HA, Peri PL, Monelos LH, Martínez Pastur G (2011) Aspectos ecológicos de la regeneración por semillas en bosques nativos de Nothofagus antarctica en Patagonia Sur, Argentina. Bosque 32:20-29

Bahamonde HA, Peri PL, Monelos LH, Martínez Pastur G (2013) Regeneración por semillas en bosques nativos de Nothofagus antarctica bajo uso silvopastoril en Patagonia Sur, Argentina. Bosque 34:89-101

Bahamonde HA, Sánchez-Gómez D, Gyenge J, Peri PL, Aranda I (2014) Interaction of light and water stress on the ecophysiological response of Nothofagus antarctica (G. Forster) Oerst. In: Book of proceedings XII PortugueseSpanish Symposium on Plant Water relations, pp 101-104 
Bahamonde HA, Peri PL, Martínez Pastur G, Monelos L (2015) Litterfall and nutrients return in Nothofagus antarctica forests growing in a site quality gradient with different management uses in Southern Patagonia. Eur J For Res 134:113-124

Bahamonde HA, Lencinas MV, Martínez Pastur G, Monelos L, Soler R, Peri PL (2016a) Ten years of seed production and establishment of regeneration measurements in Nothofagus antarctica forests under different crown cover and quality sites, in Southern Patagonia. Agrofor Syst. https://doi.org/10.1007/s10457-016-9999-7

Bahamonde HA, Sosa Lovato S, Gesto E, Martínez Pastur G, Lencinas MV, Soler R, Peri PL (2016b) Variación temporal y espacial de la humedad de suelo y las raíces finas en bosques de ñire bajo uso silvopastoril en la Patagonia sur. Book of proceedings V Jornadas Forestales, Esquel, Argentina, 9-11 de Noviembre de 2016, pp 33-37

Bréda N, Huc R, Granier A, Dreyer E (2006) Temperate forest trees and stands under severe drought: a review of ecophysiological responses, adaptation processes and longterm consequences. Ann For Sci 63:625-644

Bucci SJ, Scholz FG, Campanello PI, Montti L, JimenezCastillo M, Rockwell FA, La Manna L, Guerra P, Lopez Bernal P, Troncoso O, Enricci J, Holbrook MN, Goldstein G (2013) Hydraulic differences along the water transport system of South American Nothofagus species: do leaves protect the stem functionality? Tree Physiol 32:880-893

Calabria C, Puntieri J (2008) Desarrollo foliar y caulinar de las unidades de alargamiento de Nothofagus dombeyi (Nothofagaceae) en condiciones de alta y baja luminosidad. Bol Soc Argent Bot 43:19-30. http://www.scielo.org.ar/ scielo.php?script $=$ sci_arttext $\&$ pid $=$ S1851-2372200800010 $0002 \& \operatorname{lng}=$ es\&nrm=iso $>$. Accessed 15 Oct 2015

Collado L (2001) Los Bosques de Tierra del Fuego. Análisis de su estratificación mediante imágenes satelitales para el inventario forestal de la Provincia. Multequina 10:1-16

Corcuera L, Camarero JJ, Gil-Pelegrín E (2002) Functional groups in Quercus species derived from the analysis of pressure-volume curves. Trees Struct Funct 16(7):465472. https://doi.org/10.1007/s00468-002-0187-1

Curt T, Coll L, Prévosto B, Balandier P, Kunstler G (2005) Plasticity in growth, biomass allocation and root morpfhology in beech seedlings as induced by irradiance and herbaceous competition. Ann For Sci 62:51-60

Dettmann S, Pérez CA, Thomas FM (2013) Xylem anatomy and calculated hydraulic conductance of four Nothofagus species with contrasting distribution in South-Central Chile. Trees 27:685-696

Flexas J, Escalona JM, Medrano H (1999) Water stress induces different levels of photosynthesis and electron transport rate regulation in grapevines. Plant Cell Environ 22:39-48

García-Plazaola JI, Becerril JM (2000) Effects of drought on photoprotective mechanisms in European beech (Fagus sylvatica L.) seedlings from different provenances. Trees 14:485-490

Gargaglione V, Peri PL, Rubio G (2013) Partición diferencial de nutrientes en árboles de Nothofagus antarctica creciendo en un gradiente de calidades de sitio en Patagonia Sur. Bosque 34:291-302
Golding AJ, Johnson GN (2003) Down-regulation of linear and activation of cycling electron transport during drought. Planta 218:107-114

Hovenden MJ, Brodribb T (2000) Altitude of origin influences stomatal conductance and therefore maximum assimilation rate in Southern Beech, Nothofagus cunninghamii. Aust J Plant Physiol 27:451-456

Hovenden MJ, Vander Schoor JK (2006) The response of leaf morphology to irradiance depends on altitude of origin in Nothofagus cunninghamii. New Phytol 169:291-297

Ladd B, Peri PL, Pepper DA, Silva LCR, Sheil D, Bonser SP, Laffan SW, Amelung W, Ekblad A, Eliasson P, Bahamonde H, Duarte-Guardia S, Bird M (2014) Carbon isotopic signatures of soil organic matter correlate with leaf area index across woody biomes. J Ecol 102(6):16061611

Lajtha K, Getz J (1993) Photosynthesis and wáter use efficiency in pinyon-juniper communities along an elevation gradient in northern New Mexico. Oecologia 94:95-101

Liu F, Stützel H (2004) Biomass partitioning, specific leaf area, and water use efficiency of vegetable amaranth (Amaranthus spp.) in response to drought stress. Sci Hortic 102:15-27

Ministry of environment and sustainable development of Argentina (2015) Third national communication about climate change. http://www.ambiente.gov.ar/archivos/ web/ProyTerceraCNCC/file/02-Sumario.pdf. Accessed 2 Mar 2016

Nguyen-Queyrens A, Bouchet-Lannat F (2003) Osmotic adjustment in three-year-old seedlings of five provenances of maritime pine (Pinus pinaster) in response to drought. Tree Physiol 23:397-404

Ogaya R, Peñuelas J (2003) Comparative field study of Quercus ilex and Philly realatifolia: photosynthetic response to experimental drought conditions. Environ Exp Bot 50:137-148

Peri PL, Ormaechea SG (2013) Relevamiento de los bosques nativos de ñire (Nothofagus antarctica) en Santa Cruz: base para su conservación y manejo. Ediciones INTA web. http://inta.gob.ar/documentos/libro-201crelevamiento-delos-bosques-nativos-de-nire-nothofagus-antarctica-en-santacruz-base-para-su-conservacion-y-manejo201d. Accessed 10 Oct 2015

Peri PL, Martínez Pastur G, Lencinas MV (2009) Photosynthetic response to different light intensities and wáter status of two main Nothofagus species of southern Patagonian Forest, Argentina. J For Sci 55:101-111

Peri PL, Gargaglione V, Martínez Pastur G, Lencinas MV (2010) Carbon accumulation along a stand development sequence of Nothofagus antarctica forests across a gradient in site quality in Southern Patagonia. Forest Ecol Manag 260:229-237

Peri PL, Bahamonde HA, Lencinas MV, Gargaglione V, Soler R, Ormaechea S, Pastur GM (2016) A review of silvopastoral systems in native forests of Nothofagus antarctica in southern Patagonia, Argentina. Agrofor Syst 90(6):933-960

Piper FI, Corcuera LJ, Alberdi M, Lusk C (2007) Differential photosynthetic and survival responses to soil drought in two evergreen Nothofagus species. Ann For Sci 64:447452 
Premoli AC, Brewer CA (2007) Environmentalv. genetically driven variation in ecophysiological traits of Nothofagus pumilio from contrasting elevations. Aust J Bot 55:585591

Ramírez-Valiente JA, Sánchez-Gómez D, Aranda I, Valladares F (2010) Phenotypic plasticity and local adaptation in leaf ecophysiological traits of 13 contrasting cork oak populations under different water availabilities. Tree Physiol 30:618-627

Rasband WS (1997-2004) ImageJ. http://rsb.info.nih.gov/ij/ed. Bethesda, Maryland: National Institutes of Health

Read J, Farquhar G (1991) Comparative studies in Nothofagus (Fagaceae). I. Leaf carbon isotope discrimination. Funct Ecol 5:684-695

Read J, Hill RS, Hope GS (2010) Contrasting responses to water deficits of Nothofagus species from tropical New Guinea and high-latitude temperate forests: can rainfall regimes constrain latitudinal range? J Biogeogr 37:19621976

Sánchez-Gómez D, Robson TM, Gascó A, Gil-Pelegrín E, Aranda I (2013) Differences in the leaf functional traits of six beech (Fagus sylvatica) populations are reflected in their response to water limitation. Environ Exp Bot 87:110-119

Soler R, Martínez Pastur G, Peri PL, Lencinas MV, Pulido F (2013) Are silvopastoral systems compatible with forest regeneration? An integrative approach in southern Patagonia. Agrofor Syst 87:1213-1227

Tanai T (1986) Phytogeographic and phylogenetic history of the genus Nothofagus B1. (Fagaceae) in the southern hemisphere. Journal of the Faculty of Science, Hokkaido University, series 4, 21:505-582

Valladares F, Sanchez-Gomez D, Zavala MA (2006) Quantitative estimation of phenotypic plasticity: bridging the gap between the evolutionary concept and its ecological applications. J Ecol 94(6):1103-1116. https://doi.org/10. $1111 /$ j.1365-2745.2006.01176.x

Varela SA (2010) Respuestas morfológico-fisiológicas ante distintos tipos e intensidades de estrés en dos especies patagónicas del género Nothofagus con aptitud comercial. Master thesis, Universidad de Buenos Aires

Veblen TT, Donoso C, Kitzberger T, Rebertus AJ (1996) Ecology of Southern Chilean and Argentinean Nothofagus forests. In: Veblen TT, Hill RS, Read J (eds) The ecology and biogeography of Nothofagus forests. Yale University Press, New Haven, pp 293-353

Yin Ch, Peng Y, Zang R, Zhu Y, Li Ch (2005) Adaptative responses of Populus kangdingensis to drought stress. Physiol Plant 123:445-451 